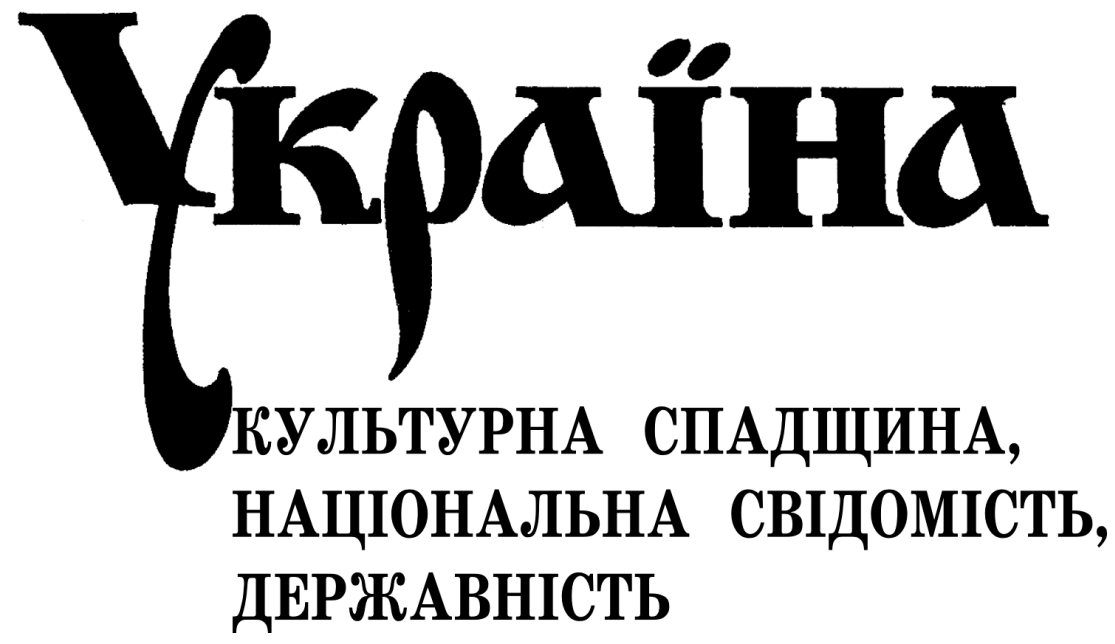

$\frac{2018}{31}$

ЛЬВІВ

त्रा 2018 
Україна: культурна спадщина, національна свідомість, державність / гол. ред. Ігор Соляр; НАН України, Інститут українознавства ім. І. Крип’якевича. Львів, 2018. Вип. 31. $308 \mathrm{c}$.

Збірник об'єднує студії з історії, мовознавства та літературознавства.

В історичному блоці представлені наукові дослідження різних аспектів актуальних проблем історії, зокрема Західноукраїнської Народної Республіки, воєнної історії, а також про відомих людей та їх значення у формуванні української державності.

Мовознавчі студії розкривають проблеми історії української філології (явища староукраїнської мови XVI-XVIII ст., дослідження пам'яток) і діалектології (діалектної лексикографіï).

Наукові публікації з літературознавства зосереджені довкола аналізу праць міжвоєнного періоду (Софія Яблонська-Уден, Михайло Рудницький) і відображають проблеми воєнного часу в сучасних текстах.

Ukraine: Cultural Heritage, National Consciousness, Statehood / Ed. Ihor Soliar; NAS of Ukraine, I. Krypiakevych Institute of Ukrainian Studies. Lviv, 2018. Vol. 31. 308 p.

The collection of scientific papers is an interdisciplinary edition of the Institute, which integrates studies in history, linguistics, and literary criticism.

The historical block is represented by studies of current problems of history, such as the history of the West Ukrainian People's Republic, military history, as well as investigations about famous persons and their importance in the formation of Ukrainian history.

Linguistic studies reveal issues in the history of Ukrainian language (phenomena in the Old Ukrainian language of the 16th-18th centuries, studies of monuments), and dialectology (dialectal lexicography).

Literary criticism studies focus on the analysis of works of the interwar period (Sofiia Yablonska-Uden, Mykhailo Rudnytskyi), and reflect the problems of wartime in contemporary texts.

Рекомендувала до друку вчена рада

Інституту українознавства ім. І. Крип’якевича НАН України

(протокол № 4 від 11.12.2018 р.)

ГОЛОВНИЙ РЕДАКТОР

Соляр Ігор Ярославович, д.і.н., с.н.с. (Україна)

РЕДАКЦІЙНА КОЛЕГІЯ:

Акіллі Алессандро (Achilli Alessandro), $\mathrm{PhD}$ (Australia)

Борчук Степан Миколайович, д.і.н., проф. (Україна)

Газдаг Вільмош (Gazdag Vilmos), PhD (Україна)

Даниленко Андрій (Danylenko Andriy), PhD, prof. (США)

Золтан Андраш (Zoltán András), dr hab., prof. (Угорщина)

Литвин Микола Романович, д.і.н., проф. (Україна)

Мозер Міхаель (Moser Michael), dr hab., prof. (Австрія)

Муравський Олег Іванович, к.і.н., с.н.с. (Україна)

Надрага Марта Степанівна, к.і.н., с.д. (Україна)

Пастух Тарас Васильович, д.філол.н., доц. (Україна)

Рембішевська Дорота Кристина (Rembiszewska Dorota Krystyna), dr hab., prof. (Польща)

Романюк Михайло Васильович, к.і.н. (Україна)

Ситник Олександр Степанович, д.і.н., проф. (Україна)

Ястремська Тетяна Олександрівна, к.філол.н., с.н.с. (Україна) 
УДК 811.161.2'28'373.7’3747’374»20»

DOI: $10.33402 / \mathrm{ukr} .2018-31-233-239$

Nataliya BAHNIUK

Candidate of Philological Sciences

Head of the Department of the Ukrainian Language

I. Krypiakevych Institute of Ukrainian studies

NAS of Ukraine

ORCID.org/0000-0001-6821-2227

e-mail:natalyabahnyuk@ukr.net

\section{RESEARCHING WRITTEN MONUMENTS \\ IN THE CONTEXT OF CHANGING SCIENTIFIC PARADIGMS}

The scientific paradigm of the 21 st century has acquired anthropocentric drift. In modern linguistic studies, the anthropocentric approach also occupies a dominant position: the researcher's attention is refocused from objects of cognition (lingual units of different levels) to the subject; thus, linguists analyze an individual in language and language in an individual.

The article presents an attempt to define the range of problems of modern linguistic diachronic researches about lingual personality, lingual consciousness, the language of the epoch.

The preconditions of involving the concept of «lingual personality» in the research arsenal of historical linguistics are analyzed. It has been found out that the text becomes a key material for studies of historical lingual personology. The language of ancient texts is studied as the expression and result of creativity of lingual personality.

Through the ancient texts of the preaching genre, the object of linguistic analysis in studies, which are analyzed in article, gradually «visualized» church-religious picture of the world as an element of the lingual picture of the world, there is an opportunity to analyze changes in it, to study the specificity of religious (confessional) linguistic personality, from religious communication at that time. It is defined that the prospective research direction is the lexicographic direction of lingual personology; the possibilities of studying the language of the epoch based on texts are analyzed.

Keywords: anthropocentric linguistic, lingual personology, lingual personality, lingual consciousness, the language of the epoch, written monuments.

In the history of linguistic science, views on the nature of lingual reality have repeatedly changed. It is during such changes, says Florii Batsevych, that in science specific forms of language are formed. The scientist points to two diametrically opposite approaches in the knowledge of the essence of language: immanent-semiological, when considering language «in and of itself», namely such principles have contributed to the formation of knowledge about language as a structure and system, and anthropological 
(or anthropocentric), within which language is studied inseparably from the inner world of $\operatorname{man}^{1}$.

In modern linguistic studies, the anthropocentric approach occupies a dominant position - in language they see the reflection of human consciousness, language is considered a cultural phenomenon and an expression of national mentality. The specificity of the anthropocentric scientific paradigm is that the researcher's attention is refocused from objects of cognition (linguistic units of different levels) to the subject, thus linguists analyze an individual in language and language in an individual. A number of directions have emerged within the anthropocentric paradigm of linguistics of the twentieth century, and within each of them language becomes the object of study in a special way.

Seeing in the language «reflection» of the individual, observing how the individual manifests itself in the language, linguists characterize the linguistic picture of the world; within communicative linguistics, interest in the individual as a participant in the communication process dominates. No less important is the study of the role of language in cognitive processes and cognitive organization of the person (using information from other sciences). Thus, language is viewed as a complex and multifaceted phenomenon by linguists in various manifestations: both as an individual's language, and as a separate unit in the family of languages, and as a structure and system, and as a space of thought and «habitation of the spirit».

At the end of the twentieth century, language was also analyzed as «a product of culture, its important component and condition of existence, as a factor in the formation of cultural codes» ${ }^{2}$.

Changing the scientific paradigm has made its footprint in the study of historical linguistics. Current scientific research on the language of Ukrainian ecclesiastical sermons (sermons) of the sixteenth and eighteenth centuries, which we analyze in this article, is a clear proof of this.

It should be noted that ancient texts related to the church and religious sphere - the lives of saints, collections of sermons of the Greek-Slavic type, gospel teaching, baroque sermons, etc., have repeatedly been the focus of Ukrainian linguists, in particular Vasyl Nimchuk, Inna Chepiha, Dmytro Hrynchyshyn, Oleh. Kupchynskyi, Ulyana Dobosevych, Halyna Chuba, Vira Franchuk, Oksana Nika, Oksana Zelinska, Ludmyla Dovha and others. The scientists analyzed the language of written monuments in detail on phoneticorthographic, word-forming, morphological, syntactic and lexical levels, characterized the defining features of linguistic stylistic organization of texts, and thus outlined the main tendencies of formation of Ukrainian written-literary language of the $16^{\text {th }}-17^{\text {th }}$ centuries.

The application of modern scientific approaches to learning the language of past eras is a complex and ambiguous problem. Taking a quick look at a series of works in which Ukrainian written monuments of different periods served as material for the study, we can conclude that anthropocentric linguistics approaches are being implemented gradually and carefully enough in the works on the history of language. Researchers have different opinions about whether ancient text can be the subject of contemporary

Бацевич Ф. С. Філософія мови: Історія лінгвофілософських учень: підручник. Київ: Видавничий центр «Академія», 2008.С. 27.

2 Маслова В. А. Лингвокультурология: учебное пособие для студ. высш. учеб. заведений. Москва: Академия, 2001. С. 6. 
discourse analysis, noting that a document of past eras is actually difficult to associate with a «text-event» or «text immersed in life»; it is not a language that is considered purposeful social action. By the way, Olena Matushek, a researcher of the baroque sermon genre, regards it as a "frozen discourse», from which the image of the author is read according to the basic model of communication «author-text-addressee». The preacher manifests himself primarily through the texts he created, and the text of the sermon in such circumstances acts as a result of text-making activity ${ }^{3}$.

Particular relevance in contemporary studies on the history of the Ukrainian language are given to the issues of reconstruction of linguistic consciousness (individual, ethnic, social), the study of the linguistic personality of the ancient and old Ukrainian period, the construction of the linguistic picture of the Ukrainian world from past epochs from its reproduced fragments. Through the ancient texts of the preaching genre, which become the object of linguistic analysis, gradually «visualized» church-religious picture of the world as an element of the linguistic picture of the world, there is an opportunity to analyze changes in it, to study the specificity of religious (confessional) linguistic personality, from religious communication at that time; after all, working with an ancient text enables one to know at least partially through the prism of language those processes that have taken place in the minds of people. Lidiya Hnatyuk also notes: «Reconstruction of the linguistic consciousness of the Ukrainian past - in a specific historical era will help to understand more deeply the laws and tendencies of the development of the Ukrainian language, in particular literary, in the projection on the human personality, more adequately to understand ancient texts and hidden behind them» ${ }^{4}$.

In each text, the «lingual personality» could be seen - this opinion was endorsed by Yurii Karaulov. According to Yurii Karaulov, the study of lingual personality begins with the identification of a hierarchy of meanings and values in its picture of the world, in its thesaurus, involves the clarification and justification of motives and goals that determine its development, behavior, control text creation ${ }^{5}$. Texts of the preaching genre of the $17^{\text {th }}$ $16^{\text {th }}$ centuries are rich material for analyzing the lingual portrait of the educated person of that time, the individual manner of the author in the way of communicating the churchreligious dogmas, characteristic features of the author's language. The linguistic fabric of Old Ukrainian church sermons is closely intertwined with traditional book-written and vernacular elements, and the spelling of the memorials is evidence of the active interaction of several orthographic traditions. «The level of bookishness or nationality of the text was determined by a set of many factors: the ideological-thematic content of the monument, its functional orientation, the chronological period, as well as the level of education of the author or copywriter, his linguistic consciousness, his personality», notes Tetiana Vydaichuk in the article «Linguistic Personality of the Old Ukrainian Age: Problems and Aspects of the Study» and adds that the monuments consistently reveal the most significant, actively perceived and learned elements of the linguistic picture of the world of the Ukrainian at that time. The researcher suggests to consider authors,

3 Матушек Е. Языковая личность украинского проповедника XVII века. Žmogus kalbos erdvejje. 6. Матеріали наукової конферениї̈ «Людина в просторах мови»: збірник наукових праць Каунаського гуманітарного факультету Вільнюського університету. Kaunas, 2010. С. 298-299.

4 Гнатюк Л. П. Мовний феномен Григорія Сковороди в контексті староукраїнської книжної традиції: монографія. Київ: Видавничий центр «Київський університет», 2010. С. 6.

5 Караулов Ю. Русский язык и языковая личность: монография. Москва: Наука, 1987. С. 37. 
copyists and compilers of ancient texts at the same time both their creators and those who can be considered as the linguistic personality of the era ${ }^{6}$.

It is also important that researchers refer to the term «linguistic personality» as not just a specific individual. Yurii Karaulov identified three levels of abstraction in the study of linguistic personality: 1) personality as author of texts and as an individual with his own character, interests, social inquiries and attitudes; 2) personality as a typical representative of a particular language community or collective; 3) personality as a representative of the human race in general ${ }^{7}$. The study of the structure of linguistic personality, its place in interpersonal and intercultural communication, individual perception of reality, the identification of types and portraits of linguistic personalities - all this makes it possible to analyze the peculiarities of the mentality of the respective society, ethnic group. V1. Karasyk in a number of works on the structure and types of linguistic personalities, in particular in the monograph «Linguistic Circle: Personality, Concepts, Discourse» (2002) introduced and argued the notion of a model personality - a typical representative of a certain circle of persons who is identified by specific characteristics, verbal and non-verbal behaviors related to its value orientations. The model personality «significantly influences the culture in general and serves as a specific symbol of that culture for representatives of other ethnic cultures. [...] Such personalities make it possible to speak about the specificity of the era ${ }^{8}$.

Reconstruction of the linguistic personality of the extraordinary figure of the past, Hrygoriy Skovoroda, based on the research of the original ones created, dedicated to L. Hnatyuk's monograph «The Linguistic Phenomenon of Hrygoriy Skovoroda in the Context of the Old Ukrainian Book Tradition» (Kyiv, 2010). The work not only substantiates the theoretical foundations, but also demonstrates their practical implementation: the researcher has identified and analyzed in detail the sources and factors that influenced the formation of Skovoroda's linguistic consciousness, such as the socio-political and cultural context of his life and work, the linguistic situation of the 18th century, educational level, etc.

Hrygorii Skovoroda's «model» linguistic personality clearly stands out against the background of the linguistic consciousness of the old Ukrainian society as a whole and of the book elite in particular, forming a holistic view of it ${ }^{9}$.

A series of modern linguistic studies of handwritten tales of the seventeenth century shows significant interest in these texts precisely from the standpoint of anthropocentric linguistics.

The material for the research by Olena Matushek «The lingual personality of the Ukrainian preacher of the $17^{\text {th }}$ century» was served by the texts of the sermons by Ioanykiy Halyatovsky, Anthony Radyvylivskyi, and Lazar Baranovych. The author analyzes the

6 Видайчук Т. Мовна особистість староукраїнської доби: проблеми та аспекти дослідження. Украйнська мова й література в сучасній школі. 2012. № 6. С. 5.

7 Русский язык: Энциклопедия / гл. ред. Ю. Н. Караулов. 2-е изд., перераб. и доп. Москва: Большая рос. энцикл., 1997. $671 \mathrm{c.}$

8 Карасик В. И. Языковой круг: личность, концепты, дискурс. Волгоград: Перемена, 2002. С. 16-17; Карасик В. И. Речевое поведение и типы языковых личностей. Массовая культура на рубеже $X X-X X I$ веков: Человек и его дискурс: сб. науч. трудов / под ред. Ю. А. Сорокина, М. Р. Желтухиной. Москва: Азбуковник, 2003. С. 30.

9 Гнатюк Л. П. Мовний феномен Григорія Сковороди в контексті староукраїнської книжної традиції: монографія. Київ: Видавничий центр «Київський університет», 2010. 446 с. 
peculiarities of the language of preachers of the $17^{\text {th }}$ century, draws conclusions about the picture of the world and the identity of perhaps the most famous speakers of the time. «Knowledge, value orientations and representations are fixed in texts as formulas, predetermined, on the one hand, by canons and traditions, and on the other by prescriptions of rhetoric and homiletics. Accordingly, the picture of the world created in the sermon is a normative world order», the researcher notes ${ }^{10}$. In her equally interesting article «The Ukrainian Sermon of the $17^{\text {th }}$ Century» Olena Matushek as «acting through words» proves that speaking is a speech act that «can have the following functions: to explain specific actions, to lead to specific actions, to interpret past concrete actions, to prepare specific actions $\gg{ }^{11}$. The interpretation of the gospel passage in the Old Ukrainian sermon was an incentive for the then-listener / reader not to passively expect God's grace, but to act actively on its way to it.

Analytical communicative-cognitive meanings embedded in the preaching texts of the $17^{\text {th }}$ century individuals, who made various corrections in the manuscript collection of sermons, devoted to the scientific investigation of Yuliya Oleshko «Manuscript collection of preaching texts of the XVII century in communicative-cognitive aspect ${ }^{12}$. The researcher found various kinds of interferences in the text, in particular: the excision of fragments containing the preacher's appeal to the audience, the author's self-characterization; correct errors or misunderstandings; recordings that extend the narrative of the sermon, etc. As the text retained to this day contains «communicative meanings, embedded in at least two or three punishments», the thesis is offered about the non-synchronous co-authorship of the studied texts and «differences in the cognitive space of the speakers», which predetermined their communicative behavior ${ }^{13}$. The factual features of sermons (deixis - the property of expression to indicate a specific spatial-temporal situation) were first the subject of analysis in the article by Yuliya Oleshko. In another publication, the author wrote on the material of a manuscript collection of eighteenth-century tales. Considered emotionality as a communicative-cognitive category that encompasses linguistic means that are used for the codified expression of emotions and capable of producing an emotional effect for the recipient ${ }^{14}$.

On the basis of selected sermons by Lazar Baranovych and Simeon Polotskyi, Nadiya Morshna revealed the peculiarities of the reception of the image of St. Oleksiy

\footnotetext{
${ }^{10}$ Матушек Е. Языковая личность украинского проповедника XVII века. Žmogus kalbos erdvéje. 6. Матеріали наукової конферениії «Людина в просторах мови»: збірник наукових праць Каунаського гуманітарного факультету Вільнюського університету. Kaunas, 2010. С. 300.

${ }^{11}$ Матушек О. Українська проповідь XVII століття як «дія за допомогою слів». Наукові записки Тернопільського національного педагогічного університету імені В. Гнатюка. Серія: Літературознавство. Тернопіль, 2010. Вип. 30. С. 72.

${ }^{12}$ Олешко Ю. Рукописний збірник Казань XVII ст. у комунікативно-когнітивному аспекті. Мовознавчий вісник: зб. наук. праць. Черкаси, 2014. Вип. 18. С. 142-146. URL: http://nbuv.gov. ua/UJRN/Mv 20141825.

13 Там само.

${ }^{14}$ Олешко Ю. Емотивність староукраїнської проповіді XVII ст. Мовні і концептуальні картини свimy. 2014. Вип. 50(2). С. 144-149. URL: http://nbuv.gov.ua/UJRN/Mikks_2014_50(2)_24.
} 
in the preaching discourse of the 17th century, detailing how a secondary ideologicalthematic structure lay on the «primary story and structure of the saint's life» ${ }^{15}$.

Analyzing contemporary research on the language personality of the preacher, we cannot ignore the monograph of the Russian researcher Adelina Salakhova «Confessional linguistic personality: communicative strategies and tactics» (2013), in which the author views the sermon as one of the key elements of religious discourse, religious communication. Every sermon, according to the linguist, can be considered a certain adaptation of the original text (Holy Scripture - N.B.) to the capabilities / level of human perception ${ }^{16}$. This adaptation may take the form of a full or partial translation of the original text in a more accessible language, resulting in expanded or concise versions of the source text, the study of which will decode key information that has been accumulated in the text-making process.

In general, the genre of preaching of $16-17^{\text {th }}$ centuries in Ukrainian linguistics is not sufficiently studied from the standpoint of anthropocentric linguistics. The urgency of such an analysis of the texts of the sermons is dictated, according to O. Nika, by the general nature of the orator-preaching genre («entice to hear»), which includes interactivity, dialogism, procedural, interpretative, functional syncretic (informative, cognitive-expressive, emotional) use expressive means due to this peculiarities of textual production, as well as «new approaches to their study from the standpoint of communicative and cognitive linguistics, linguocultural science, linguosemiotics, linguopoetics ${ }^{17}$.

\section{REFERENCES}

1. Batsevych, F. S. (2008). Filosofiia movy: Istoriia linhvofilosofskykh uchen: pidruchnyk. Kyiv: Vydavnychyi tsentr «Akademiia» [in Ukrainian].

2. Hnatiuk, L. P. (2010). Movnyi fenomen Hryhoriia Skovorody v konteksti staroukrainskoi knyzhnoi tradytsii: monohrafiia. Kyiv: Vydavnychyi tsentr «Kyivskyi universytet» [in Ukrainian].

3. Karasik, V. Y. (2002). Yazykovoi kruh: lichnost, kontsepty, dyskurs: monohrafiia. Volgograd: Peremena [in Russian].

4. Karasik, V. Y. (2003). Rechevoe povedenye i tipy yazykovykh lichnostei. In Yu. A. Sorokina, M. R. Zheltukhyna(Ed.), Massovaia kultura na rubezhe XX-XXI vekov: Chelovek i eho dyskurs: sb. nauch. trudov (pp. 24-44). Moscow: Azbukovnik [in Russian].

5. Karaulov, Yu. (1987). Russkii yazyk i yazykovaia lichnost: monohrafiia. Moscow: Nauka [in Russian].

6. Karaulov, Yu. N. (Ed.). (1997). Russkii yazyk: Entsyklopedyia (2 rev. ed). Moscow: Bolshaia rosiiskaia entsyklopediia [in Russian].

7. Maslova, V.A. (2001). Linhvokulturolohiia: uchebnoe posobiie. Moscow: Akademiia [in Russian].

${ }^{15}$ Моршна Н. В. Проповідницький дискурс житія св. Олексія, чоловіка Божого в українській літературі доби Бароко. Наукові записки НаУКМА. Філологічні науки. 2011. Т. 124. С. 20.

${ }^{16}$ Салахова А. Конфессиональная языковая личность: коммуникативные стратегии и тактики: монография. Челябинск: Энциклопедия, 2013. С. 45.

17 Ніка О. І. Казання першої половини XVII ст. у лінгвістичному висвітленні. Нові дослідження пам'яток козаиької доби в Україні: зб. наук. праць. Київ: Центр пам'яткознавства НАН України і УТОПІК, 2012. Вип. 21, ч. 1. С. 249. 
8. Matushek, E. (2010). Yazykovaia lichnost ukrainskoho propovednyka XVII veka. Proceedings of the Scientific Conference: Žmogus kalbos erdveje. «Liudyna v prostorakh mov». (pp. 298-306). Kaunas. [in Russian].

9. Matushek, O. (2010). Ukrainska propovid XVII stolittia yak «diia za dopomohoiu sliv». Naukovi zapysky Ternopilskoho natsionalnoho pedahohichnoho universytetu imeni V. Hnatiuka. Seriia: Literaturoznavstvo, 30, 67-76 [in Ukrainian].

10. Morshna, N. V. (2011). Propovidnytskyi dyskurs zhytiia sv. Oleksiia, cholovika Bozhoho v ukrainskii literaturi doby Baroko. Naukovi zapysky Natsionalnoho universytetu «Kyievo-Mohylianska akademiia». Filolohichni nauky, 124, 16-20 [in Ukrainian].

11. Nika, O. I. (2012). Kazannia pershoi polovyny XVII st. u linhvistychnomu vysvitlenni. Novi doslidzhennia pamiatok kozatskoi doby v Ukraini: Zbirnyk naukovykh prats. Kyiv: Tsentr pamiatkoznavstva NAN Ukrainy i UTOPIK, 21 (1), 249-254 [in Ukrainian].

12. Oleshko, Yu. (2014). Emotyvnist staroukrainskoi propovidi XVII st. Movni i kontseptualni kartyny svitu, 50 (2), 144-149 [in Ukrainian].

13. Oleshko, Yu. (2014). Rukopysnyi zbirnyk Kazan XVII st. u komunikatyvno-kohnityvnomu aspekti. Movoznavchyi visnyk: zbirnyk naukovykh prats. Cherkaskyi natsionalnyi universytet im. Bohdana Khmelnytskoho, 18, 142-146 [in Ukrainian].

14. Salakhova, A. (2013). Konfessionalnaia yazykovaia lichnost: kommunikativnye stratehii i taktiki: monohrafiia. Chelyabinsk: Entsyklopediia [in Russian].

15. Vydaichuk, T. (2012). Movna osobystist staroukrainskoi doby: problemy ta aspekty doslidzhennia. Ukrainska mova i literatura v suchasnii shkoli, 6, 4-7 [in Ukrainian].

\section{Наталія БАГНЮК}

ДОСЛІДЖЕННЯ ПИСЕМНИХ ПАМ' ЯТОК У КОНТЕКСТІ ЗМІНИ НАУКОВИХ ПАРАДИГМ

Наукова парадигма XXI ст. набула антропоцентричного спрямування. Антропоцентричний підхід поступово займає ключові позиції і в сучасних мовознавчих студіях: дослідницький фокус лінгвістів перемістився з об'єктів пізнання (мовних одиниць різних рівнів) на суб’єкт, відтак вивчають людину в мові й мову в людині.

У статті зроблено спробу окреслити коло питань, пов'язаних із вивченням мовної особистості, мовної свідомості, мови епохи у діахронному аспекті.

Проаналізовано передумови залучення поняття «мовна особистість» до дослідницького арсеналу історичної лінгвістики. 3'ясовано, що саме текст стає ключовим матеріалом для студій з історичної лінгвоперсонології. У фокусі мовознавців - мова давніх текстів як вияв і результат творчості мовної особистості.

Крізь мовну канву давніх текстів проповідницького жанру, які є об'єктом аналізу у студіях, взятих до уваги у статті, рельєфно проявляється церковно-релігійна картина світу як елемент мовної картини світу, виникає змога аналізувати зміни в ній, вивчати специфіку релігійної мовної особистості, тогочасної релігійної комунікації.

Перспективними визначено можливості вивчення мовної особистості минулих епох на матеріалі давніх текстів.

Ключові слова: антропоцентрична лінгвістика, лінгвоперсонологія, мовна особистість, мовна свідомість, мова епохи, писемні пам'ятки. 


\section{MICT}

\section{ІСТОРИЧНІ СТУДІї}

Актуальні питання української історії ........................

Мисак Наталія. Ідеї соборності та самостійності

в українському молодіжному середовищі Галичини

наприкінці XIX - початку XX століття. . . . . . . . . . . . . . . 3

Фіногенов Олег. «Ліонський сюжет» (1924)

у діяльності Західноукраїнського товариства Ліги Націй. . . . . . . . . . 16

Стасюк Олександра. Роль рад депутатів трудящих у процесі радянізації Західних областей УРСР (1939-1941) . . . . . . . . . . . . . 26

Лук'янченко Світлана. Агропромисловий комплекс Рівненської області

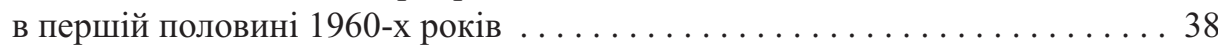

До 100-річчя ЗУНР................................ 46

Дацків Ігор. Діяльність зовнішньополітичної служби

Західноукраїнської Народної Республіки в 1918-1923 роках . . . . . . . . . 46

Королько Андрій. Становлення і функціонування органів

української влади на Снятинщині періоду ЗУНР (1918-1919) . . . . . . . . 54

Пірко Марія. Видавничі проекти державного секретаріату ЗУНР . . . . . . . . 79

Ткачук Павло, Кривизюк Леонід. Участь польових духівників у життєдіяльності збройних сил ЗУНР. . . . . . . . . . . . . 88

Пагіря Олександр. ЗУНР і національно-визвольний рух на Закарпатті в 1918-1919 роках. ................................ 100

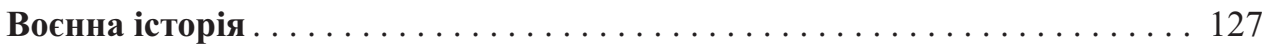

Ткачук Андрій. Політика безпеки в коаліційній угоді депутатських фракцій у Верховній раді України $\mathrm{V}$ скликання . . . . . . . 127

Попко Сергій. Державна програма співробітництва України з НАТО на 2001-2004 роки: пріоритети та завдання у контексті євроатлантичної інтеграції. . . . . . . . . . . . . . . . . . 137

Постаті .......................................... 145

Сова Андрій. Внесок Івана Боберського в підготовку та проведення

Шевченківського здвигу 1914 року у Львові . . . . . . . . . . . . . 145

Патер Іван. Суспільно-політичні процеси в Галичині 1919-1920 року в оцінці Євгена Чикаленка (за матеріалами «Щоденника») . . . . . . . . . . . 156

Соляр Ігор. Дмитро Левицький у визвольних змаганнях українців у $1914-1923$ роках. ............................... 170 
Середюк Марія. Громадсько-політична діяльність Володимира Целевича в роки національно-визвольних змагань (1918-1923) . . . . . . . . . . . . 181

Каменцев Денис. «Мене завжди тішило й почасти дивувала та велика напружена праця, яку переводять наші вояки...»: роль Володимира Сальського в організації української військової еміграції (1921-1940) . . . . . . . . . . . . . . . . . . . . . . . . . . . . 190

Кравець Наталія. Національно-культурна діяльність Василя Проходи в таборах військовополонених у роки Першої світової війни . . . . . . . . . 203

\section{МОВОЗНАВСТВО}

Осінчук Юрій. Лексика на позначення Божих Осіб, святих і ангелів в українському історичному словнику за редакцією Євгена Тимченка. . . . . 213

Bahniuk Nataliya. Researching written monuments in the context

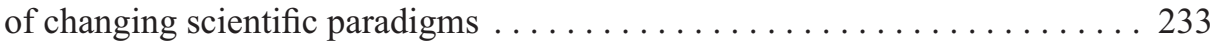

Черевко Ірина. Здобутки української діалектної фразеографії ХХІ століття . . . . . . . . . . . . . . . . . . . . . . . . . . . . 240

\section{ЛІТЕРАТУРОЗНАВСТВО}

Гаврилів Тимофій. Ідентичнісні імплікації: «3 країни рижу та опію» Софії Яблонської-Уден . . . . . . . . . . . . . . . . . . . . . . . . . . . . 251

Когут Софія. Видавничі стратегії Михайла Рудницького міжвоєнного періоду: ідеї, проекти, перспективи . . . . . . . . . . . . . . . 267

Рутар Христина. Мандрівка до (своєї) пам’яті: міжвоєнний Львів і Львів у часі Другої світової війни в сучасному українському тексті (на матеріалі романів «Музей покинутих секретів» Оксани Забужко й «Танго смерті» Юрія Винничука) . . . . . . . . . . . . . . . . . . 278

\section{ОГЛЯДИ ТА РЕЦЕНЗЇ̈}

Лановик Мар'яна. [Рец.]: «Пов'язати розгублені кінці життя і мистецтва» [на]: Мочернюк Н. Поза контекстом: Інтермедіальні стратегії літературної творчості українських письменників-художників міжвоєння: монографія. Львів: Вид-во Львівської політехніки, 2018. 392 с. + 16 кольор. вкл. . . . . . 286

Романюк Михайло. [Рец. на]: Сова А., Тимчак Я. Іван Боберський основоположник української тіловиховної і спортової традиції / за наук. ред. Євгена Приступи. Львів: ЛДУФК, Апріорі, 2017. 232 с. . . . . 295

Yastremska Tetiana. Dialectological studies: history, topics, structure . . . . . . 300 